\title{
Smart heating sleeping bags for improving wearers' thermal comfort at the feet
}

\author{
Chengjiao Zhang ${ }^{1}$, Dandan Lai ${ }^{1}$, Yehu Lu' ${ }^{1}$, Faming Wang ${ }^{1 *}$, Kalev Kuklane ${ }^{2}$ \\ From 15th International Conference on Environmental Ergonomics (ICEE XV) \\ Portsmouth, UK. 28 June - 3 July 2015
}

\begin{abstract}
Introduction
Sleeping bags are portable products, which are essential for sleeping outdoors. Generally, a sleeping bag is comprised of an outer layer, an inner lining layer and the filler. The EN 13537 (2012) and ASTM F1720 (2014) standards are widely used to determine the thermal insulation of sleeping bags by means of thermal manikin. Previous studies have found that local thermal discomfort at feet was often seen despite the mean skin temperature was well within thermoneutral range under the defined comfort and limit temperature [1]. Thus, it is meaningful to design smart heating sleeping bags to improve the local thermal comfort of the users. In this study, a novel smart sleeping bag was developed by incorporating heating fabrics into the feet region of the bag. The physiological and psychological responses when using traditional sleeping bag and the smart sleeping bag were investigated and compared.
\end{abstract}

\section{Methods}

Two smart sleeping bags used at different temperatures were developed. The thermal insulation of those two sleeping bags, Vau (V) and Mar (M), were first measured by a thermal manikin 'Newton' (Measurement Technology Northwest, Seattle, USA) according to EN 13537 (2012) [2]. For each bag, two test scenarios were selected: heating off (i.e., CONTROL) and heating on (i. e., ON). The heating power was set at $20 \mathrm{~W}$. Eight subjects (four females) participated in this study. The test duration was 3 hours. The comfort temperature of the sleeping bags $\mathrm{V}$ and $\mathrm{M}$ was $5.5^{\circ} \mathrm{C}$ and $-0.5{ }^{\circ} \mathrm{C}$, respectively. The limit temperature was $0.5{ }^{\circ} \mathrm{C}$ and $-6.4{ }^{\circ} \mathrm{C}$,

\footnotetext{
* Correspondence: dr.famingwang@gmail.com

'Laboratory for Clothing Physiology and Ergonomics (LCPE), the National Engineering Laboratory for Modern Silk, Soochow University, Suzhou, 215123 China

Full list of author information is available at the end of the article
}

respectively. The $\mathrm{RH}$ and wind speed for all tests were $80 \%(5 \%)$ and $0.4(0.1) \mathrm{m} . \mathrm{s}^{-1}$, respectively. Subjective perceptions (e.g., whole body and local thermal sensation, comfort sensation and skin wetness) were collected $15 \mathrm{~min}$ before the trial, the beginning of the trial, the 20th min and the 180th min of the trial. Physiological responses, i.e., oxygen consumption, blood flow, and heart rate were measured throughout each human trial. The mean skin temperature $\left(\mathrm{T}_{\mathrm{sk}}\right)$ was calculated by the Gagge and Nishi's 8-point equation.

\section{Results}

For the CONTROL, it was found that the temperatures at the left fourth toe and the left foot fell continuously linear dropping throughout the 3-hour testing period, for male, the mean toe temperature declined from $25.5^{\circ}$ $\mathrm{C}$ and $24.9{ }^{\circ} \mathrm{C}$ to $14.6{ }^{\circ} \mathrm{C}$ and $15.4{ }^{\circ} \mathrm{C}$ for $\mathrm{V}$ and $\mathrm{M}$, respectively; for female, the mean toe temperature decreased from $25.3^{\circ} \mathrm{C}$ and $25.1{ }^{\circ} \mathrm{C}$ to $17.6{ }^{\circ} \mathrm{C}$ and 18.2 ${ }^{\circ} \mathrm{C}$ for $\mathrm{V}$ and $\mathrm{M}$, respectively. The mean foot temperature has the similar tendency with that of toes. Besides, strong cold and uncomfortable feeling at feet was observed for most subjects. However, the $\mathrm{T}_{\text {sk }}$ well stayed within the thermoneutral range (i.e., $32-34{ }^{\circ} \mathrm{C}$ ) throughout the whole test. For all testing scenarios with heating on (i.e., $\mathrm{ON}$ ), the toe and foot temperatures of all subjects were well maintained above $22.0{ }^{\circ} \mathrm{C}$ and $30.0{ }^{\circ} \mathrm{C}$, respectively. The local thermal and comfort sensation denoted that subjects were in thermal neutral conditions.

\section{Discussion}

This laboratory study validated that the introduction of the heating fabric could improve the subject's thermal and comfort sensation. It has proven that the smart heating sleeping bag could keep the users foot and toe remaining comfort throughout the testing period under 
defined temperature. Besides, the newly developed smart sleeping bags could significantly improve local thermal comfort under the defined wear temperature. However, it was evident that heating at foot region has no obvious effect on the $\mathrm{T}_{\mathrm{sk}}$. This study also confirmed again that the EN 13537 (2012) defined temperature only focus the whole body thermal balance, with less regard on the extremities (i.e., the feet and toes).

\section{Authors' details}

'Laboratory for Clothing Physiology and Ergonomics (LCPE), the National Engineering Laboratory for Modern Silk, Soochow University, Suzhou, 215123 China. ${ }^{2}$ Thermal Environment Laboratory, Department of Design Sciences, Lund University, Lund, Sweden.

Published: 14 September 2015

\section{References}

1. Lin LY, Wang F, Kuklane K, Gao C, Holmér I, Zhao M: A laboratory validation study of comfort and limit temperatures of four sleeping bags defined according to EN 13537(2002). Applied Ergonomics 2012, 44(2):321-326.

2. EN 13537: Requirements for Sleeping Bags. European Committee for Standardization, Brussels. 2012.

doi:10.1186/2046-7648-4-S1-A92

Cite this article as: Zhang et al: Smart heating sleeping bags for improving wearers' thermal comfort at the feet. Extreme Physiology \& Medicine 2015 4(Suppl 1):A92.

\section{Submit your next manuscript to BioMed Central} and take full advantage of:

- Convenient online submission

- Thorough peer review

- No space constraints or color figure charges

- Immediate publication on acceptance

- Inclusion in PubMed, CAS, Scopus and Google Scholar

- Research which is freely available for redistribution

Submit your manuscript at www.biomedcentral.com/submit
C Biomed Central 